\title{
PENGARUH NILAI PELANGGAN DAN KUALITAS LAYANAN TERHADAP KEPUASAN DAN DAMPAKNYA TERHADAP LOYALITAS PELANGGAN MAXX COFFEE BENTON JUNCTION LIPPO KARAWACI, TANGERANG, BANTEN
}

\author{
Kentzi $^{1}$, Innocentius Bernarto ${ }^{2}$, Dewi Wuisan ${ }^{3}$ \\ *Correspondence Author: bernarto227@gmail.com
}

\section{1,2,3 Fakultas Ekonomi dan Bisnis, Universitas Pelita Harapan, Tangerang, Banten}

\begin{abstract}
The growing retail business of coffee shops in Indonesia makes retail companies need to be able face big competitive competition in the market in order to maintain their existence. The purpose of this study is to find out whether customer value and service quality could have positive influence to customer satisfaction, and to know whether customer satisfaction have positive influence to customer loyalty of Maxx Coffee Benton Junction Lippo Karawaci. Data collection was done by using questionnaire instrument. The population in this study were the customer of Maxx Coffee Benton Junction Lippo Karawaci. The number of samples in this study were 100 respondents with convenience sampling technique. In performing statistical analysis, PLS-SEM (Partial Least Squares-Structural Equation Modeling) was used with using SmartPLS 3.2.7 as the software. The results showed that customer value and service quality have positive influence to customer satisfaction and customer satisfaction have positive influence to customer loyalty of Maxx Coffee Benton Junction Lippo Karawaci. Keywords: Customer Value, Service Quality, Customer Satisfaction, and Customer Loyalty
\end{abstract}

\begin{abstract}
Abstrak: Bisnis ritel kedai kopi yang semakin berkembang di Indonesia membuat perusahaan ritel harus mampu menghadapi persaingan besar di pasar untuk mempertahankan eksistensinya. Tujuan dari penelitian ini adalah untuk mengetahui apakah nilai pelanggan dan kualitas layanan berpengaruh positif dan terhadap kepuasan pelanggan, dan untuk mengetahui apakah kepuasan pelanggan berpengaruh positif terhadap loyalitas pelanggan Maxx Coffee Benton Junction Lippo Karawaci, Tangerang. Pengumpulan data dilakukan dengan menggunakan instrumen kuesioner. Populasi dalam penelitian ini adalah seluruh pelanggan Maxx Coffee Benton Junction Lippo Karawaci. Jumlah sampel dalam penelitian ini adalah 100 responden dengan teknik pengambilan sampel kenyamanan. Dalam melakukan analisis statistik, PLSSEM (Partial Least Squares-Structural Equation Modeling) diterapkan dengan menggunakan SmartPLS 3.2.7 sebagai perangkat lunak. Hasil penelitian menunjukkan bahwa nilai pelanggan dan kualitas layanan berpengaruh positif terhadap kepuasan pelanggan dan kepuasan pelanggan berpengaruh positif terhadap loyalitas pelanggan Maxx Coffee Benton Junction Lippo Karawaci, Tangerang.

Kata Kunci: Nilai Pelanggan, Kualitas Layanan, Kepuasan Pelanggan, Loyalitas Pelanggan

Bisnis ritel mengalami perkembangan yang pesat di Indonesia. Bisnis ritel sendiri merupakan serangkaian kegiatan usaha yang memberikan nilai tambah pada produk dan jasa yang dijual kepada pelanggan untuk penggunaan pribadi atau keluarga (Levy, 2009). Bisnis ritel di Indonesia sudah memasuki era yang praktis yang sama dengan negara maju lainnya dimana membuat semua pelaku bisnis menjadi lebih mudah untuk membuka sebuah bisnis baru di Indonesia. Asosiasi Pengusaha Ritel Indonesia
\end{abstract}


(Aprindo) mengungkapkan, pada tahun 2016 terjadi peningkatan 10 persen pada industri ritel nasional dan hal ini diakui terjadi selaras dengan adanya perbaikan perekonomian Indonesia pada tahun tersebut (Marta, 2016).

Di dalam sebuah bisnis, pada bagian pemasaran dapat dikategorikan berhasil apabila mampu membuat konsumen atau calon konsumen membeli dan menggunakan produknya tersebut. Keputusan konsumen di dalam pembelian inilah yang akan membuat proses pemasaran terlihat efektif atau tidak. Ketika konsumen melalui proses pemilihan hingga akhirnya melakukan proses pembelian maka akan menentukan keberlangsungan pemasaran produk yang baik. Rasa puas yang didapatkan oleh konsumen akan membuat sebuah pemikiran tersendiri di dalam benak konsumen untuk melakukan konsumsi produk atau jasa tersebut. Perusahaan ritel harus dapat mengendalikan situasi dimana memberikan kepuasan bagi konsumen akan keberadaaan produk atau jasa yang ditawarkan untuk mendapatkan keinginan konsumen di dalam melakukan pembelian ulang.

Loyalitas pelanggan yang didapatkan oleh perusahaan melalui kualitas layanan yang baik terhadap pelanggan dan disertai dengan adanya rasa puas akan penggunaan produk di dalamnya. Konsumen yang merasa puas dengan produk yang dibelinya akan menjadi setia dan akan membagikan informasi yang positif terhadap produk yang dibelinya (Kotler dan Armstrong 2016). Kesetiaan yang didapatkan ini secara tidak langsung akan menguntungkan sisi perusahaan untuk semakin dikenal dan menjaga eksistensinya dengan menjaga hubungan baik dengan pelanggan setia.

Bisnis ritel khususnya yang bergerak kepada bisnis kedai kopi mengalami perkembangan yang signifikan pada beberapa tahun belakangan ini. Kedai kopi menjadi sebuah bisnis yang menjanjikan dengan peluang yang besar dan hal ini mengakibatkan adanya pertumbuhan di dalam terciptanya bisnis pada industri dan pasar ini. Berdasarkan hasil riset Indonesia Coffee Organization, pada tahun 2012 mengatakan bahwa pertumbuhan konsumsi kopi di Indonesia lebih banyak dua persen dibandingkan pertumbuhan yang ada di dunia (Investments, 2015).

Nilai merupakan sesuatu yang penting bagi bisnis kedai kopi ini, dimana nilai yang diberikan dari produk minuman mereka akan penting dan terbentuk pada pikiran pelanggan. Nilai dapat tercipta pada pikiran pelanggan melalui kualitas dari pelayanan yang diberikan di dalam menyediakan produk dari sebuah merek tersebut. Hal ini tidak lepas dari kualitas pelayanan yang juga baik yang berarti tidak hanya mementingkan produk namun juga jasa yang ditawarkannya. Parasuraman, Zeithaml, dan Berry (1998) mengemukakan lima dimensi dari kualitas jasa yakni tangibles, reliability, responsiveness, asurance, dan emphaty. Dimensi tersebut yang akan mengantarkan pelanggan untuk mendapatkan kepuasan (Mardikawati dan Naili, 2013). Rasa puas kembali lagi didapatkan oleh masing-masing pelanggan melalui nilai yang muncul melalui atribut-atribut pemasaran yang ada untuk mempengaruhi pembelian. Apabila melalui pembelian ini mampu memenuhi ekspektasi dan kebutuhan akanlah terjadi pembelian ulang yang mengarahkan konsumen menjadi setia (Paliliati, 2007).

Maxx Coffee dan Starbucks adalah contoh bisnis kedai kopi ritel yang besar di Indonesia, yang bersaing secara bersama di dalam menyediakan permintaan peminat kopi pada pasar Indonesia. Perkembangan industri ini dimulai oleh Starbucks yang membuka gerai pertama di Indonesia pada tahun 2002, sebagai peritel asing yang merupakan pelopor di bidang kopi yang terkenal di dunia. Starbucks menawarkan konsep vintage yang memiliki kenyaman dan menyebut setiap gerai yang ada sebagai rumah ketiga bagi penggila kopi. Konsep rumah ketiga ini setelah keluarga dan ruang lingkup aktifitas lain (Wulandari, 2015). Starbucks menawarkan kenyamanan dan ketenangan yang membuat para pelanggan merasakan layaknya seperti di rumah 
mereka sendiri. Sedangkan kedai kopi lokal yang menjadi pesaing Starbucks ini adalah Maxx Coffee yang merupakan anak perusahaan Lippo Group yang masih baru di dalam industri ini (Wulandari, 2015). Maxx coffee tidak hanya melihat bisnis mereka memiliki kenyamanan saja, tetapi juga ingin menjadikan Maxx Coffee ini sebagai Melting Pot yang merupakan tempat nyaman bagi para komunitas masyarakat dapat berkumpul. Selain itu, Maxx Coffee juga dapat disaingkan dengan Starbucks dari segi penjualan, terungkap bahwa pada kuartal I/2017 memiliki pendapatan 141.74 miliar Rupiah meskipun Starbucks jauh di atasnya dengan penjualan 208,74 miliar Rupiah (Heksa, 2017). Dengan berdasarkan hal tersebut, dapat dikatakan Maxx Coffee mampu menyaingi Starbucks sebagai pebisnis lokal dengan potensi penjualan yang baik.

Riset awal dilakukan untuk mengetahui practical gap dengan wawancara singkat kepada sepuluh mahasiswa/i Fakultas Ekonomi dan Bisnis UPH yang pernah mengunjungi Maxx Coffee Benton Junction, Lippo Karawaci, Tangerang, dan juga kepada manajer salah satu gerai Maxx Coffee. Berdasarkan wawancara singkat dengan manajer Maxx Coffee, terungkap bahwa dari sepuluh pelanggan, manajer mengharapkan enam pelanggan adalah loyal atau $60 \%$ pelanggan loyal. Sedangkan hasil wawancara singkat dengan sepuluh mahasiswa/i menunjukkan bahwa dari sepuluh mahasiswa/i, hanya empat mahasiswa/i (40\%) yang sering bertransaksi di Maxx Coffee. Dengan demikian terdapat gap pada loyalitas pelanggan Maxx Coffee. Oleh karena itu, untuk meningkatkan jumlah pelanggan yang loyal agar sesuai dengan harapan manajer tesebut, maka digunakan model penelitian dari Mardikawati dan Naili (2013). Model tersebut terdiri dari variabel nilai pelanggan, kualitas layanan, kepuasan pelanggan dan loyalitas pelanggan. Variabel nilai pelanggan dan kualitas layanan berpengaruh positif terhadap variabel kepuasan pelanggan dan selanjutnya kepuasan pelanggan berpengaruh positif terhadap loyalitas pelanggan. Variabel nilai pelanggan dan kualitas layanan merupakan variabel independen. Kemudian variabel kepuasan pelanggan adalah variabel intervening dan variabel loyalitas pelanggan adalah variabel dependen.

Penelitian ini selain dari tujuan praktis, yaitu untuk mengatasi permasalahan dari Maxx Coffee, juga mempunyai tujuan teoritis yakni untuk memverifikasi apakah model penelitian Mardikawati dan Naili (2013) berlaku sama untuk konteks yang berbeda. Oleh karena itu, penelitian ini adalah penelitian replikasi. Pertanyaan penelitian adalah apakah nilai pelanggan dan kualitas layanan berpengaruh positif terhadap kepuasan. Kemudian apakah kepuasan berpengaruh positif terhadap loyalitas pelanggan.

\section{Kepuasan Pelanggan}

Schiffman dan Wisenbilt (2015) mengartikan kepuasan pelanggan atau customer satisfaction sebagai persepsi pelanggan dari performa atau kemampuan produk atau jasa di dalam hubungan memenuhi ekspektasi mereka. Apabila kemampuan suatu produk dan jasa tersebut mampu memenuhi harapan yang ada maka pelanggan akan merasakan puas. Rasa puas yang dirasakan pada pelanggan akan menimbulkan keuntungan bagi perusahaan. Apabila ketika melakukan pembelian atau konsumsi oleh pelanggan tidak didapatkan kepuasan atau tidak memenuhi ekspektasi maka akan muncul ketidakpuasan yang akan merugikan perusahaan. Perusahaan dengan pemasar yang baik akan berusaha untuk memuaskan pelanggan demi keberlangsungan jangka panjang. Mothersbaugh dan Hawkins (2016) mengemukakan dimana kepuasan bergerak sebagai pendorong penting dari loyalitas pelanggan dan banyak organisasi melakukan investasi di dalamnya untuk meningkatkan kepuasan pelanggan. Dapat dikemukakan bahwa seorang pelanggan yang puas akan lebih cenderung menetap 
terhadap suatu merek dan melakukan proses pembelian ulang dengan adanya persepsi yang kuat dan kepercayaan untuk bertahan. Rasa puas yang didapatkan akan menciptakan persepsi yang baik di benak pelanggan dan mampu membawa dampak positif bagi perusahaan ataupun sebuah merek.

Pelanggan biasanya menghadapi beragam produk dan layanan yang mungkin memenuhi kebutuhan tertentu. Di dalam proses pemilihan, pelanggan akan membentuk ekspektasi tentang nilai dan kepuasan yang dapat ditawarkan. Pelanggan yang puas akan membeli lagi dan memberi tahu kepada orang lain tentang pengalaman bagus yang dirasakan. Hal ini terjadi kepada pelanggan yang lainnya dimana, pelanggan yang tidak puas akan beralih kepada pasar lain dan produk lain. Pemasaran disini harus lebih berhatihati di dalam menetapkan tingkat ekspektasi yang tepat. Apabila harapan yang ditetapkan terlalu rendah, mungkin akan memuaskan orang-orang yang membeli tetapi gagal untuk menarik pembeli dalam jumlah banyak. Jika terlalu tinggi ekspektasinya, pembeli akan merasa kecewa. Kepuasan pelanggan dan nilai yang didapatkan oleh pelanggan merupakan dasar utama untuk mengembangkan dan mengelola hubungan dengan pelanggan. (Kotler dan Armstrong, 2016).

Hoffman dan Bateson (2011) mengemukakan bahwa dengan memuaskan pelanggan dapat menghasilkan beberapa keuntungan seperti kata positif dari mulut ke mulut yang dihasilkan dari pelanggan lama yang dapat menguntungkan perusahaan untuk meraih lebih banyak pelanggan baru. Perusahaan yang memiliki peringkat kepuasan pelanggan yang tinggi memiliki kemampuan untuk melindungi diri sendiri dari tekanan persaingan, khususnya persaingan harga. Melalui pelanggan yang puas berarti perusahaan mampu untuk memastikan posisi mereka pada pasar persaingan harga. Selain itu, pelanggan bersedia membayar lebih tinggi dan tinggal pada perusahaan yang memenuhi kebutuhan daripada mengambil resiko beralih ke perusahaan dengan penawaran layanan dan harga lebih rendah. Pada akhirnya, perusahaan yang membanggakan diri pada usaha untuk memenuhi kepuasan pelanggan umumnya memberikan lingkungan yang lebih baik untuk bekerja.

\section{Loyalitas Pelanggan}

Perusahaan untuk terus dapat bertahan pada pasar persaingan harus dapat mempertahankan pelanggan dan mampu untuk menarik banyaknya pelanggan baru. Perusahaan perlu untuk menjaga rasa loyalitas pelanggan dengan selalu bisa memenuhi kebutuhan dan keinginan pelanggan serta memenuhi semua harapan atau ekspektasi yang ada dengan baik.

Fitzsimmons (2015) menjelaskan bahwa perusahaan mapan pasti akan menggunakan atau memberikan pelayanan secara personal untuk membuat dasardasar pelanggan menjadi setia sehingga hal ini akan menjadi penghalang bagi masuknya layanan baru. Loyalitas pelanggan merupakan hal yang paling dicari oleh suatu perusahaan karena dengan adanya pelanggan yang setia akan membuat perusahaan semakin berkembang dan menjadi penguasa pasar dengan banyaknya pelanggan baru dan pelanggan setia.

Menurut Kotler dan Armstrong (2016) dengan menjaga loyalitas pelanggan atau kesetiaan pelanggan terhadap perusahaan akan menjaga kualitas perekonomian perusahaan dalam artian akan menjaga stabilitas ekonomi perusahaan. Pelanggan yang loyal akan menghabiskan lebih banyak dan bertahan untuk tinggal lebih lama. Diketahui juga dimana akan lebih murah untuk mempertahankan pelanggan lama daripada mencari pelanggan yang baru. Hal ini pun yang juga menjelaskan dengan kehilangan pelanggan berarti kehilangan satu penjualan yang akan menghilangkan arus pembelian yang akan dilakukan pelanggan seumur hidupnya. 
Hoffman dan Bateson (2011) mengatakan bahwa loyalitas pelanggan mencerminkan keterikatan emosional pelanggan dengan perusahaan. Loyalitas tidak berlaku ketika tidak ada produk lain yang ditawarkan oleh perusahaan lain. Namun, ketika banyak pesaing maka akan sangat penting bagi perusahaan untuk menjaga kesetiaan pelanggan agar pelanggan tidak pindah produk perusahaan lainnya. Loyalitas pelanggan merupakan keyakinan yang lebih terhadap perusahaan dan tanpa adanya ini tidak akan menjadi retensi pelanggan. Suatu layanan tidak bisa hanya memikirkan hubungan yang kuat tetapi perlu memahami nilai strategis loyalitas pelanggan yang lebih baik.

\section{Kaitan antara Nilai Pelanggan dengan Kepuasan Pelanggan}

Perusahaan di dalam mempertahankan posisi pada pasar dan untuk menguasai pada pasar persaingan perlu untuk memenuhi kemauan dan kebutuhan pelanggan. Kepuasan yang didapatkan oleh pelanggan akan membuat dan mengarahkan kepada pembelian berulang pada masa depan. Nilai pelanggan ini yang akan membantu di dalam membuat kepuasan pada pelanggan yang bergantung kepada bagaimana nilainilai yang didapatkan oleh pelanggan benar-benar diserap dengan baik ataupun tidak. Selain itu, nilai pelanggan oleh perusahaan yang benar akan membuat pelanggan untuk melihat bagaimana produk yang dikonsumsi akan memuaskan mereka.

Nilai pelanggan bagi suatu perusahaan dapat menjadi penilaian tersendiri di dalam menjaga performa yang ada dan menjadikan evaluasi untuk perubahan kepuasan pelanggan. Mothersbaugh dan Hawkin (2016) mengatakan bahwa melalui nilai pelanggan, kepuasan atau ketidakpuasan pelanggan diperoleh dari produk yang dibelinya. Berdasarkan penelitian Harpedeles, Jushermi dan Nursanti (2016); Munisih dan Soliha (2015) menunjukkan bahwa nilai pelanggan memiliki pengaruh positif terhadap kepuasan pelanggan dimana setiap nilai pelanggan yang meningkat akan meningkatkan kepuasan pelanggan. Selanjutnya, Hami dan Hidayat (2016) juga mendapati hasil yakni nilai pelanggan berpengaruh positif terhadap kepuasan pelanggan. Berdasarkan penjelasan tersebut didapatkan hipotesis sebagai berikut:

\section{H1: Nilai pelanggan berpengaruh positif terhadap kepuasan pelanggan.}

\section{Kaitan antara Kualitas Layanan dengan Kepuasan}

Kualitas layanan merupakan salah satu hal yang dijadikan pertimbangan di dalam sebuah perusahaan jasa dan juga produk dalam usaha memenuhi kebutuhan dan keinginan pelanggan. Kualitas pelayanan yang baik pastinya akan membuat pelanggan merasa terpenuhi dan puas baik dari segi produk maupun pelayanan. Maxx Coffee merupakan kedai kopi yang tidak hanya mementingkan penjualan semata namun juga ingin melayani pelanggan sebaik mungkin dengan kualitas terbaik yang ada. Layanan yang baik cenderung akan menciptakan kepuasan bagi setiap pelanggan.

Kepuasan pelanggan sendiri merupakan keadaan atau perasaan seseorang baik senang maupun kecewa terhadap hasil yang diberikan oleh sebuah produk ataupun jasa (Kotler \& Keller 2016). Ketika layanan itu tidak memenuhi ekspektasi pelanggan akan menjadi ketidakpuasan dan ketika hal tersebut melebihi ekspektasi akan menghasilkan kepuasan. Pada penelitian terdahulu oleh Aryani dan Rosinta (2010) menemukan bahwa kelima dimensi pembentuk kualitas layanan memiliki pengaruh secara signifikan terhadap kualitas layanan dimana sangat kuat dan positif terbukti melalui hasil yang ada. Di dalam penelitian lainnya oleh Sasongko dan Subagio (2013) ditemukan bahwa variabel responsiveness dalam kualitas layanan memberikan pengaruh yang dominan dibandingkan yang lainnya di dalam kualitas layanan terhadap 
kepuasan pelanggan. Selain itu, Utami dan Jatra (2015) mengemukakan variabelvariabel di dalam kualitas layanan memberikan pengaruh yang positif dan signifikan terhadap kepuasan pelanggan di dalamnya dimana masing-masing secara parsial mempengaruhi. Berdasarkan penjelasan tersebut didapatkan hipotesis sebagai berikut:

$\mathrm{H}_{2}$ : Kualitas layanan berpengaruh positif terhadap kepuasan pelanggan.

\section{Kaitan antara Kepuasan Pelanggan dengan Loyalitas Pelanggan}

Pelanggan memiliki penilaian tersendiri di dalam merasakan kepuasan terhadap suatu produk dan pelayanan yang ada dari sebuah perusahaan. Perusahaan perlu untuk melihat bagaimana dengan memuaskan kebutuhan dan keinginan pelanggan akan menghasilkan kesetiaan yang menguntungkan bagi pihak perusahaan dan menyenangkan bagi pelanggan. Tetapi kepuasan yang dirasakan oleh pelanggan tidak selalu dapat membuat mereka terus menjadi pelanggan atau menciptakan kesetiaan dan pelanggan yang tidak puas juga tidak selalu meninggalkan perusahaan. Kepuasan merupakan faktor penting bagi perusahaan untuk melihat bagaimana pelanggan akan terus menetap ataupun memiliki niatan untuk berpindah.

Kepuasan tidak selalu menjamin loyalitas pelanggan karena kesetiaan tercipta tidak hanya karena rasa puas tetapi ketika halangan untuk keluar dan berpindah juga besar. Di dalam penelitian yang dilakukan oleh Musanto (2004) menunjukkan dimana faktor-faktor di dalam kepuasan pelanggan seperti sales experience mempunyai pengaruh signifikan terhadap loyalitas pelanggan dimana banyak variabel di dalam faktor kepuasan pelanggan lainnya tidak berpengaruh. Penelitian oleh Suliyanto (2013) menemukan adanya pengaruh yang diberikan oleh nilai pelanggan dan kepuasan pelanggan yang secara bersamaan terhadap loyalitas pelanggan. Pencapaian kepuasan pelanggan di dalamnya melalui peningkatan nilai pelanggan itu sendiri. Ditambahkan lagi dari penelitian Nurafni, Rahman, dan Hidayat (2016) bahwa kepuasan pelanggan memberikan pengaruh positif kepada loyalitas pelanggan. Berdasarkan penjelasan tersebut didapatkan hipotesis sebagai berikut:

H3: Kepuasan pelanggan berpengaruh positif terhadap loyalitas pelanggan. 
Berdasarkan hipotesis tersebut dapat digambarkan model penelitian seperti gambar berikut:

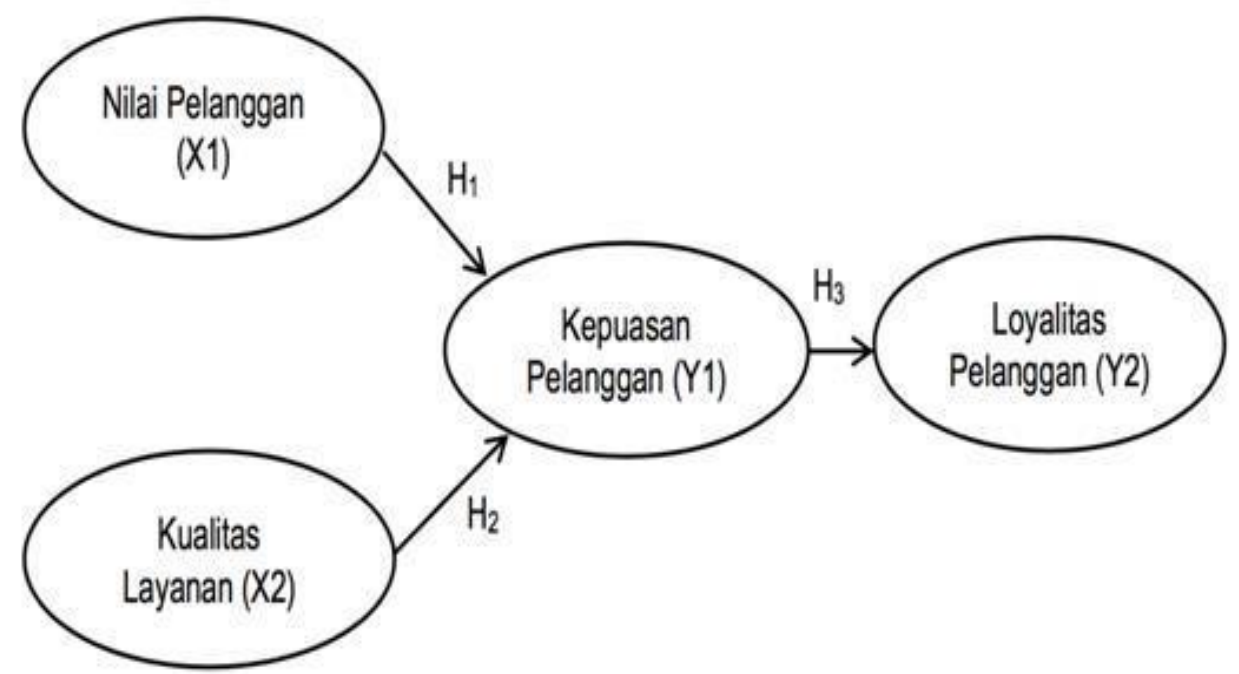

Gambar 1. Model Penelitian (Mardikawati dan Naili ,2013)

\section{METODE}

Tipe penelitian adalah penelitian kuantatif. Metode pengumpulan data dilakukan dengan wawancara dan angket atau kuesioner. Teknik wawancara dilakukan dengan wawancara singkat kepada sepuluh mahasiswa dan seorang manajer Maxx Coffee untuk mengidentifikasi problem loyalitas. Sedangkan kuesioner digunakan untuk mendapatkan data pada variabel nilai pelanggan, kualitas layanan, kepuasan pelanggan dan loyalitas pelanggan. Unit analisis dalam penelitian ini adalah individu yakni pelanggan Maxx Coffee Benton Junction Lippo Karawaci. Teknik yang digunakan untuk pengambilan sampel adalah dengan convenience sampling. Jumlah sampel yang diperoleh sebanyak 100 responden. Pengukuran sikap dengan menggunakan 5 poin Likert Scale. Analisis statistik yang digunakan dalam penelitian ini adalah partial least square-structural equation modeling (PLS-SEM) dengan bantuan program SmartPls 3.2.7. Analisis data dilakukan dalam dua tahap yaitu outer model dan inner model. Uji instrumen yakni uji validitas dan uji reliabilitas dilakukan dalam tahap outer model. Sedangkan uji hipotesis dilakukan pada tahap inner model.

\section{Model Pengukuran}

Dalam tahapan ini dilakukan pengujian validitas dan reliabilitas instrumen. Validitas terdiri dari validitas konverjen dan validitas diskriminan. Uji validitas konverjen dilakukan dengan memperhatikan nilai average variance extracted (AVE) yang mana nilai tersebut harus lebih besar dari 0.5 untuk setiap variabel. Kemudian, dari setiap variabel, nilai outer loading untuk setiap item harus lebih besar dari 0.7 (Hair, Hult, Ringle, \& Sarstedt, 2014). Namun, sepanjang nilai AVE lebih besar dari 0.5, maka nilai outer loading di bawah 0.7 masih dapat diterima (Hair et al, 2014).

Selanjutnya, uji reliabilitas diukur dengan cronbach alpha dan composite reliability. Ghozali dan Latan (2014) mengatakan bahwa pengujian reliabilitas sebaiknya diukur dengan composite reliability (CR). Persyaratan yang harus dipenuhi untuk uji reliabilitas adalah nilai composite reliability harus lebih besar dari 0.7 (Hair et al, 2014). Tabel 1 menunjukkan hasil uji validitas konverjen dan uji reliabilitas. Nilai AVE berkisar 0.500 hingga 0.760 . Kemudian nilai outer loading untuk setiap item berkisar 0.541 hingga 0.917 . Berikutnya, nilai composite reliability berkisar 0.873 
hingga 0.950 . Dengan demikian hasil pengukuran validitas konverjen dan reliabilitas telah memenuhi persyaratan.

Tabel 1. Hasil uji validitas dan reliabilitas

\begin{tabular}{|c|c|c|}
\hline \multicolumn{2}{|c|}{ Variabel dan item } & Outer Loading \\
\hline \multicolumn{3}{|c|}{ Nilai Pelanggan $(\mathrm{AVE}=0.500 ; \mathrm{CR}=0.873)$} \\
\hline NP1 & Maxx coffee memiliki nilai lebih dibandingkan kompetitornya & 0.734 \\
\hline NP2 & Harga yang ditawarkan Maxx Coffee sesuai dengan fasilitas yang ada & 0.777 \\
\hline NP3 & Lokasi Maxx Coffee mudah dijangkau & 0.541 \\
\hline NP4 & Maxx Coffee dapat memenuhi kebutuhan pelanggan & 0.808 \\
\hline NP5 & $\begin{array}{l}\text { Maxx Coffee dapat memberikan manfaat melalui produk yang } \\
\text { ditawarkan }\end{array}$ & 0.763 \\
\hline NP6 & Maxx Coffee memberikan pelayanan dengan tepat & 0.598 \\
\hline NP7 & $\begin{array}{l}\text { Maxx Coffee memberikan pelayanan dengan kemampuan yang baik } \\
\text { kepada saya }\end{array}$ & 0.689 \\
\hline \multicolumn{3}{|c|}{ Kualitas Layanan $(\mathrm{AVE}=0.630 ; \mathrm{CR}=0.894)$} \\
\hline KL1 & Pelayanan yang diberikan Maxx Coffee terasa nyaman & 0.668 \\
\hline KL2 & Bagi saya, Maxx Coffee memberikan perhatian kepada saya & 0.861 \\
\hline KL3 & Pekerja Maxx Coffee memahami apa yang dibutuhkan oleh saya & 0.817 \\
\hline KL4 & $\begin{array}{l}\text { Pekerja Maxx Coffee memberikan solusi terbaik terhadap keluhan } \\
\text { yang ada }\end{array}$ & 0.819 \\
\hline KL5 & Pekerja Maxx Coffee selalu siap membantu kebutuhan memenuhi saya & 0.791 \\
\hline \multicolumn{3}{|c|}{ Kepuasan Pelanggan $(\mathrm{AVE}=0.657 ; \mathrm{CR}=0.930)$} \\
\hline KP1 & Maxx Coffee memberikan produk sesuai harapan saya & 0.808 \\
\hline KP2 & Menurut saya, harga yang ditawarkan Maxx Coffee "worth it" & 0.740 \\
\hline KP3 & Maxx Coffee memberikan layanan yang sesuai dengan harapan saya & 0.797 \\
\hline KP4 & Saya setia dengan Maxx Coffee & 0.865 \\
\hline KP5 & Saya merekomendasikan Maxx Coffee kepada teman saya & 0.872 \\
\hline KP6 & Saya bersedia memberikan ide atau masukkan kepada Maxx Coffee & 0.681 \\
\hline KP7 & Saya puas dengan Maxx Coffee & 0.890 \\
\hline \multicolumn{3}{|c|}{ Loyalitas Pelanggan $(\mathrm{AVE}=0.760 ; \mathrm{CR}=0.950)$} \\
\hline LP1 & $\begin{array}{l}\text { Saya berkeinginan untuk mengkonsumsi produk Maxx Coffee terus } \\
\text { menerus }\end{array}$ & 0.860 \\
\hline LP2 & Saya menjadikan Maxx Coffee sebagai pilihan utama & 0.913 \\
\hline LP3 & Saya tidak mudah untuk berpindah dari Maxx Coffee & 0.917 \\
\hline LP4 & Saya membela Maxx Coffee terhadap perilaku buruk dari pesaing & 0.865 \\
\hline LP5 & Saya mengatakan hal positif tentang Maxx Coffee & 0.832 \\
\hline LP6 & Saya akan datang kembali ke Maxx Coffee & 0.840 \\
\hline
\end{tabular}

Keterangan : AVE = averange variance of extracted; $\mathrm{CR}=$ composite Reliability.

Sumber: Hasil olah data, 2019

Uji validitas diskriminan dilakukan dengan menggunakan kriteria FornellLarcker dan cross loading (Ghozali \& Latan, 2014). Dalam penelitian ini uji validitas diskriminan dengan menggunakan kriteria crosss loading. Tabel 2 menunjukkan evaluasi validitas diskriminan dengan kriteria cross loading. Seperti yang terlihat pada tabel 2 yakni indikator/item KL1 hingga KL 5 memiliki nilai outer loading yang paling besar pada variabel KL (kualitas layanan) dibandingkan dengan variabel lainnya. Dengan demikian variabel KL dapat memprediksi indikator/item KL 1 hingga KL5 paling tinggi dibandingkan dengan variabel lainnya. 
Tabel 2. Cross Loading

\begin{tabular}{|c|c|c|c|c|}
\hline & KL & KP & LP & NP \\
\hline KL1 & 0.668 & 0.660 & 0.537 & 0.641 \\
\hline KL2 & 0.861 & 0.695 & 0.618 & 0.626 \\
\hline KL3 & 0.817 & 0.619 & 0.554 & 0.614 \\
\hline KL4 & 0.819 & 0.621 & 0.574 & 0.554 \\
\hline KL5 & 0.791 & 0.625 & 0.460 & 0.551 \\
\hline KP1 & 0.611 & 0.808 & 0.674 & 0.691 \\
\hline KP2 & 0.535 & 0.740 & 0.619 & 0.614 \\
\hline KP3 & 0.762 & 0.797 & 0.580 & 0.677 \\
\hline KP4 & 0.706 & 0.865 & 0.827 & 0.666 \\
\hline KP5 & 0.727 & 0.872 & 0.838 & 0.696 \\
\hline KP6 & 0.512 & 0.681 & 0.661 & 0.517 \\
\hline KP7 & 0.739 & 0.890 & 0.798 & 0.743 \\
\hline LP1 & 0.541 & 0.736 & 0.860 & 0.615 \\
\hline LP2 & 0.630 & 0.808 & 0.913 & 0.625 \\
\hline LP3 & 0.582 & 0.764 & 0.917 & 0.597 \\
\hline LP4 & 0.663 & 0.736 & 0.865 & 0.560 \\
\hline LP5 & 0.638 & 0.827 & 0.832 & 0.607 \\
\hline LP6 & 0.574 & 0.758 & 0.840 & 0.655 \\
\hline NP1 & 0.600 & 0.700 & 0.697 & 0.734 \\
\hline NP2 & 0.561 & 0.594 & 0.475 & 0.777 \\
\hline NP3 & 0.295 & 0.335 & 0.261 & 0.541 \\
\hline NP4 & 0.651 & 0.674 & 0.568 & 0.808 \\
\hline NP5 & 0.614 & 0.644 & 0.562 & 0.763 \\
\hline NP6 & 0.399 & 0.433 & 0.341 & 0.598 \\
\hline NP7 & 0.509 & 0.530 & 0.423 & 0.689 \\
\hline $\begin{array}{l}\text { Keterangan: } \\
\text { LP=loyalita }\end{array}$ & $\begin{array}{l}\text { as layan } \\
; \mathrm{NP}=\mathrm{ni}\end{array}$ & $\begin{array}{l}\text { epuasan } \\
\text { gan. }\end{array}$ & & \\
\hline
\end{tabular}

Sumber: Hasil olah data, 2019

Tabel 3 menunjukkan bahwa nilai $\mathrm{R}^{2}$ pada variabel kepuasan pelanggan (KP) adalah $0.756(7506 \%)$ dan loyalitas pelanggan (LP) adalah 0.788 (78.8\%). Makna dari nilai $\mathrm{R}^{2}$ tersebut adalah bahwa kepuasan pelanggan dapat dijelaskan oleh variabel nilai pelanggan dan kualitas layanan sebesar $75.6 \%$ dan sisanya sebesar $24.4 \%$ dijelaskan oleh variabel lainnya. Selanjutnya, $\mathrm{R}^{2}$ loyalitas pelanggan sebesar $78.8 \%$ yang artinya loyalitas pelanggan dapat diprediksi oleh kepuasan pelanggan. Sisanya sebesar $21.2 \%$ dapat diprediksi oleh variabel lainnya.

Tabel 3. Nilai R-square

\begin{tabular}{cc}
\hline Variabel & $\mathbf{R}_{2}$ \\
\hline Kepuasan Pelanggan & 0.756 \\
\hline Loyalitas Pelanggan & 0.788 \\
\hline
\end{tabular}

Sumber: Hasil olah data, 2019 
Selanjutnya uji hipotesis dilakukan dengan uji statistik yaitu membandingkan nilai thitung dengan ttabel. Dalam penelitian ini digunakan level of significant sebesar 5\% atau nilai tabel $=1.65$, one-tailed test. Jika nilai thitung $>$ nilai tabel $(=1.65)$, maka keputusannya adalah didukung. Namun, jika thitung $<$ tabel $(=1.65)$, maka hipotesisnya tidak didukung. Tabel 4 menunjukkan bahwa seluruh hipotesis didukung atau signifikan.

Tabel 4. Hasil Uji Hipotesis

\begin{tabular}{lccc}
\hline \multicolumn{1}{c}{ Hipotesis } & $\begin{array}{c}\text { Standardized } \\
\text { Coefficient }\end{array}$ & thitung & Keputusan \\
\hline $\begin{array}{l}\text { Nilai Pelanggan berpengaruh positif terhadap Kepuasan } \\
\text { Pelanggan Maxx Coffee Benton Junction Lippo } \\
\text { Karawaci }\end{array}$ & 0.462 & 5.075 & Didukung \\
\hline $\begin{array}{l}\text { Kualitas Layanan berpengaruh positif terhadap Kepuasan } \\
\text { Pelanggan Maxx Coffee Benton Junction Lippo } \\
\text { Karawaci }\end{array}$ & 0.466 & 5.063 & Didukung \\
\hline $\begin{array}{l}\text { Kualitas Layanan berpengaruh positif terhadap Loyalitas } \\
\text { Pelanggan Maxx Coffee Benton Junction Lippo } \\
\text { Karawaci }\end{array}$ & 0.888 & 50.025 & Didukung \\
\hline
\end{tabular}

Sumber: Hasil olah data, 2019

Tabel 5 menunjukkan pengaruh tidak langsung nilai pelanggan terhadap loyalitas pelangggan melalui kepuasan pelanggan sebesar 0.410. Kemudian pengaruh tidak langsung kualitas layanan terhadap loyalitas melalui kepuasan sebesar 0.414 . Hal ini mengungkapkan bahwa pengaruh kualitas layanan terhadap loyalitas lebih besar dibandingkan dengan pengaruh nilai pelanggan terhadap loyalitas.

Tabel 5. Indirect Effect

\begin{tabular}{lc}
\hline \multicolumn{1}{c}{ Jalur } & Indirect effects \\
\hline Kualitas Layanan $\rightarrow$ Kepuasan Pelanggan $\rightarrow$ Loyalitas Pelanggan & 0.414 \\
\hline Nilai Pelanggan $\rightarrow$ Kepuasan Pelanggan $\rightarrow$ Loyalitas Pelanggan & 0.410 \\
\hline
\end{tabular}

Sumber: Hasil olah data, 2019

\section{HASIL DAN PEMBAHASAN}

Berdasarkan hasil pengujian hipotesis pertama yang menyatakan bahwa Nilai pelanggan berpengaruh positif terhadap kepuasan pelanggan Maxx Coffee Benton Junction Lippo Karawaci. Nilai yang semakin baik didapatkan oleh pelanggan akan menciptakan rasa puas terhadap suatu produk dan pelayanan yang diberikan. Mardikawati dan Naili (2013) menyatakan bahwa nilai pelanggan mengindikasikan hubungan yang kuat terhadap kepuasan pelanggan dimana semakin tinggi nilai yang diinginkan tercapai maka akan semakin kuat rasa puas yang terciptakan. Pada hipotesis pertama, nilai thitung $(=5.075)$ lebih besar dari pada tabel $(1.65)$. Oleh karena itu hipotesis pertama, didukung. Hasil pengujian ini konsisten dengan penelitian sebelumnya oleh Hami dan Hidayat (2016); Harpedeles, Jushermi dan Nursanti, (2016); Munisih dan Soliha (2015).

Berikutnya, hasil uji hipotesis kedua yang menyatakan bahwa kualitas layanan berpengaruh positif terhadap kepuasan pelanggan Maxx Coffee Benton Junction Lippo Karawaci adalah didukung. Nilai thitung $(=5.063)$ lebih besar dari pada nilai tabel $(=1,65)$. Hasil pengujian ini sesuai dengan hasil penelitian dari Mardikawati dan Naili (2013). Kualitas layanan atau pemberian layanan yang baik oleh penyedia jasa kepada pelanggan akan membuat mereka menciptakan rasa puas pelanggan terhadap Maxx Coffee di Benton Junction Lippo Karawaci. Rasa puas merupakan suatu keadaan 
pelanggan yang merasakan kecewa maupun senang terhadap hasil dari sebuah produk maupun jasa yang ditawarkan oleh penyedia jasa (Kotler dan Keller, 2016).

Terakhir, hipotesis ketiga yang menyatakan bahwa kepuasan pelanggan berpengaruh positif terhadap Loyalitas Pelanggan Maxx Coffee Benton Junction Lippo Karawaci, didukung. Hipotesis ini mendapatkan hasil thitung sebesar 50.025 yang berarti lebih besar dari tabel 1.65. Hal ini membuktikkan bahwa hasil ini signifikan dan selaras dengan penelitian sebelumnya oleh Aryani dan Rosinta (2010); Mardikawati dan Naili (2013); Sasongko dan Subagio (2013); Utami dan Jatra (2015). Loyalitas dapat terbentuk ketika pelanggan mendapatkan sesuatu yang baik dari penyedia produk ataupun jasa dan dapat juga dikarenakan kepuasan yang didapatkan atas suatu produk ataupun jasa. Kepuasan pelanggan akan bergerak sebagai pendorong dari loyalitas pelanggan sehingga secara tidak langsung membuktikan bahwa rasa puas yang didapatkan pelanggan akan menciptakan kesetiaan pelanggan (Mothersbaugh dan Hawkins, 2016). Secara menyeluruh, hasil penelitian ini konsisten dengan penelitian sebelumnya oleh Mardikawati dan Naili (2013). Keseluruhan hipotesis didukung dan berpengaruh positif.

Hasil pengaruh tidak langsung atau indirect effects menunjukkan bahwa kedua variabel nilai pelanggan dan kualitas layanan berpengaruh positif secara tidak langsung di dalam menciptakan loyalitas pelanggan. Makna dari pengaruh positif di sini adalah ketika jasa yang diterima atau dirasakan sesuai dengan yang diharapkan, maka akan menghasilkan persepsi yang baik dan memuaskan sehingga dapat memberikan pengaruh kepada loyalitas pelanggan. Sebaliknya ketika jasa yang diterima lebih rendah atau tidak sesuai dengan harapan pelanggan, akan menghasilkan persepsi buruk dan terjadinya penurunan kepuasan pelanggan yang akan menyebabkan menurunnya loyalitas terhadap perusahaan. Kemudian hasil uji indirect effects dapat diinterpretasikan bahwa ketika pihak manajemen berkeinginan untuk meningkatkan tingkat loyalitas pelanggan, maka tindakan pertama yang harus dilakukan pihak manajemen Maxx Coffee adalah dengan meningkatkan kualitas layanannya, seperti, pihak manajemen dapat memahami kebutuhan, tidak enggan untuk membantu dan memberikan perhatian yang baik kepada pelanggan.

Tindakan berikutnya adalah dengan memperhatikan dan meningkatkan nilai pelanggan, misalnya manajemen Maxx Coffee secara eksplisit menunjukkan manfaat mengkonsumsi ataupun memanfaatkan fasilitas yang ada pada Maxx Coffee. Kemudian manajemen juga harus dapat meminimalkan service failure terhadap kebutuhan pelanggan. Kesalahan order produk ataupun pencatatan tagihan merupakan faktor yang penting di dalam peningkatkan nilai pelanggan yang berpengaruh terhadap loyalitas pelanggan dan dapat berdampak kepada menurunnya profit yang didahului dengan menurunnya total revenue Maxx Coffee.

\section{SIMPULAN}

Berdasarkan hasil pengolahan dan analisis data, maka kesimpulan dari penelitian adalaha pertama, nilai pelanggan berpengaruh positif terhadap kepuasan pelanggan. Ketika manajemen Maxx Coffee hendak meningkatkan kepuasan pelanggan, maka nilai pelanggan harus dttingkatkan. Kedua, kualitas layanan berpengaruh positif terhadap kepuasan Pelanggan. Oleh karena itu, ketika kualitas layanan meningkat, maka kepuasan pelanggan juga meningkat.Terakhir, kepuasan pelanggan berpengaruh positif terhadap loyalitas pelanggan Maxx Coffee. Dengan demikian, semakin tinggi kepuasan pelanggan, maka loyalitas pelanggan juga meningkat. 


\section{DAFTAR RUJUKAN}

Aryani, D., \& Rosinta, F. (2010). Pengaruh kualitas layanan terhadap kepuasan pelanggan dalam membentuk loyalitas pelanggan. Jurnal Ilmu Administrasi dan Organisasi, Bisnis \& Birokrasi Journal, 17(2), 114-126.

Cooper, D.R., \& Schindler, P. M. (2014). Business research methods. New York: McGraw-Hill/Irwin.

Fitzsimmons, J. A., Fitzsimmons, M. J., \& Bordoloi, S. (2015). Service management: operations, strategy, information technology. Beijing: China Machine Press.

Ghozali, I., \& Latan, H. (2014). Partial least squares: Konsep, teknik, dan aplikasi menggunakan program Smartpls 3.0. Semarang: Universitas Diponegoro.

Hami, M. L., S., \& Hidayat, K. (2016). Analisis pengaruh nilai pelangan terhadap kepuasan pelanggan dan dampaknya pada loyalitas pelanggan. Jurnal Administrasi Bisnis,39(1), 81-89.

Hair, J.F., Hult, G. T. M., Ringle, C. M., \& Sarstedt, M. (2014). A primer on partial least squares structural equation modeling (PLS-SEM). Los Angeles: SAGE Publications, Inc.

Harpadeles, I., Jushermi, J., \& Nursanti, A. (2016). Pengaruh kualitas pelayanan dan nilai pelanggan terhadap kepuasan dan loyalitas pelanggan Trans Metro Pekanbaru. Jurnal Online Mahasiswa Fakultas Ekonomi Riau, 3(1), 43-56.

Heksa, (2017, April 04). Starbucks catatkan kenaikan laba di Indonesia sepanjang 2016. Retrieved June 14, 2017, From Http://Www.Franchiseglobal. Com/Starbucks-Catatkan-Kenaikan-Laba-Di-Indonesia-Sepanjang-2016.Phtml

Hoffman, K. D., \& Bateson, J. E. G. (2011). Services marketing: Concepts, strategies, \& cases.Mason, O.H.: South-Western Cengage Learning

Investments, I. (2015, October 8). Kopi. Retrieved June 14, 2017, From

Https://Www.Indonesia-Investments.Com/Id/Bisnis/Komoditas/Kopi/Item186 Kotler, P., \& Armstrong, G. (2016). Principles of marketing. Hoboken: Pearson Higher Education.

Kotler,P., \& Keller, K. L. (2016). Marketing management. England: Pearson Education Limited.

Levy, M. (2009), WEB 2.0 implications on knowledge management, Journal of Knowledge Management, 13(1), 120-134.

Mardikawati, W, \& Naili, F. (2013). Pengaruh nilai pelanggan dan kualitas layanan terhadap loyalitas pelanggan, melalui kepuasan pelanggan pada pelanggan bus Efisiensi (Studi PO Efisiensi jurusan Yogyakarta-Cilacap), Jurnal Administrasi Bisnis, 2(1), 64-74.

Marta, M. F. (2016, December 28). Aprindo: Industri ritel tumbuh sekitar 10 persen pada 2016. Retrieved June 14, 2017, From Http://Bisniskeuangan. Kompas. Com/Read/2016/12/28/172204826/Aprindo.Industri.Ritel.Tumbuh.Sekitar.10. Persen.Pada.2016

Mothersbaugh, D. L., Hawkins, D. I., Mothersbaugh, L. L., \& Tom, G. (2016). Consumer behavior building marketing strategy. New York, N.Y.: Mcgraw-Hill Education.

Musanto, T. (2004). Faktor-faktor kepuasan pelanggan dan loyalitas pelanggan: Studi kasus pada CV. Sarana Media Advertising Surabaya. Jurnal Manajemen \& Kewirausahaan,6(2), 123-136.

Nurafni. Rahman, A., \& Hidayat. (2016). Pengaruh kepuasan terhadap loyalitas konsumen pada swalayan Smart Pasir Pengaraian. E-jurnal Mahasiswa Prodi Manajemen, 3(1), 1-9. Retrieved June 10, 2017 from http://e-journal.upp.ac.id index. php/fekon/article/view/666/557 
Paliliati, A. (2007). Analisis pengaruh nilai pelanggan, kepuasan terhadap loyalitas nasabah tabungan perbankan di Sulawesi Selatan. Jurnal Manajemen dan Kewirausahaan, 9(1), 73-81.

Parasuraman, A., Zeithaml, V.A., \& Berry, L.L. (1998), SERVQUAL: A multiple item scale for Measuring consumer perceptions of service quality, Journal of Retaling, 64(1), 12-40.

Sasongko, F., \& Subagio, D. (2013). Pengaruh kualitas layanan terhadap kepuasan pelanggan restoran Ayam Penyet Ria. Jurnal Manajemen Pemasaran Petra, 1(2), 1-7.

Schiffman, L. G., \& Wisenblit, J. (2015). Consumer Behavior. Boston: Pearson.

Suliyanto. (2013). Pengaruh nilai pelanggan dan kepuasan pelanggan terhadap loyalitas pelanggan: Switching cost sebagai variabel moderasi. Jurnal Ekonomi dan Bisnis, 12(1), 11-18.

Utami, I. A.I. S., \& Jatra, I. M. (2015). Pengaruh kualitas layanan terhadap kepuasan pelanggan restoran Baruna Sanur. E-Jurnal Manajemen Unud, 4(7), 19842000.

Wulandari, D. (2015). Tergiur bisnis coffee shop, Lippo Group luncurkan Maxx Coffee. Retrieved June 15, 2017, From Http://Mix.Co.Id/Marcomm/NewsTrend/Tergiur-Bisnis-Coffee-Shop-Lippo-Group-Luncurkan-Maxx-Coffee 